\title{
Oral susceptibility of aedine and culicine mosquitoes (Diptera: Culicidae) to Batai Orthobunyavirus
}

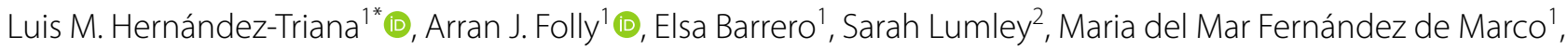
Sanam Sewgobind ${ }^{1}$, Lorraine M. McElhinney ${ }^{1}$, Anthony R. Fooks ${ }^{1}$ and Nicholas Johnson ${ }^{1}$

\begin{abstract}
Background: A number of zoonotic mosquito-borne viruses have emerged in Europe in recent decades. Batai virus (BATV), a member of the genus Orthobunyavirus, is one example of a relatively newly emerged mosquito-borne virus, having been detected in mosquitoes and livestock. We conducted vector competency studies on three mosquito species at a low temperature to assess whether Aedes and Culex mosquito species are susceptible to infection with BATV.
\end{abstract}

Methods: Colonised lines of Aedes aegypti and Culex pipiens and a wild-caught species, Aedes detritus, were orally inoculated with BATV strain 53.2, originally isolated from mosquitoes trapped in Germany in 2009. Groups of bloodfed female mosquitoes were maintained at $20^{\circ} \mathrm{C}$ for 7 or 14 days. Individual mosquitoes were screened for the presence of BATV in body, leg and saliva samples for evidence of infection, dissemination and transmission, respectively. BATV RNA was detected by reverse transcription-PCR, and positive results confirmed by virus isolation in Vero cells.

Results: Aedes detritus was highly susceptible to BATV, with an infection prevalence of $\geq 80 \%$ at both measurement time points. Disseminated infections were recorded in 30.7-41.6\% of Ae. detritus, and evidence of virus transmission with BATV in saliva samples ( $n=1$, days post-infection: 14 ) was observed. Relatively lower rates of infection for Ae. aegypti and $C x$. pipiens were observed, with no evidence of virus dissemination or transmission at either time point.

Conclusions: This study shows that Ae. detritus may be a competent vector for BATV at $20^{\circ} \mathrm{C}$, whereas Ae. aegypti and $C x$. pipiens were not competent. Critically, the extrinsic incubation period appears to be $\leq 7$ days for Ae. detritus, which may increase the onward transmissibility potential of BATV in these populations.

Keywords: Batai virus, Vector competence, Aedes, Culex, Emerging infectious diseases, Zoonosis

\footnotetext{
*Correspondence: luis.hernandez-triana@apha.gov.uk

${ }^{1}$ Vector-Borne Diseases Research Team, Virology Department, Animal

and Plant Health Agency, Woodham Lane, Addlestone KT15 3NB, Surrey,

UK

Full list of author information is available at the end of the article
} permits use, sharing, adaptation, distribution and reproduction in any medium or format, as long as you give appropriate credit to the original author(s) and the source, provide a link to the Creative Commons licence, and indicate if changes were made. The images or other third party material in this article are included in the article's Creative Commons licence, unless indicated otherwise in a credit line to the material. If material is not included in the article's Creative Commons licence and your intended use is not permitted by statutory regulation or exceeds the permitted use, you will need to obtain permission directly from the copyright holder. To view a copy of this licence, visit http://creativecommons.org/licenses/by/4.0/. The Creative Commons Public Domain Dedication waiver (http://creativeco mmons.org/publicdomain/zero/1.0/) applies to the data made available in this article, unless otherwise stated in a credit line to the data. 


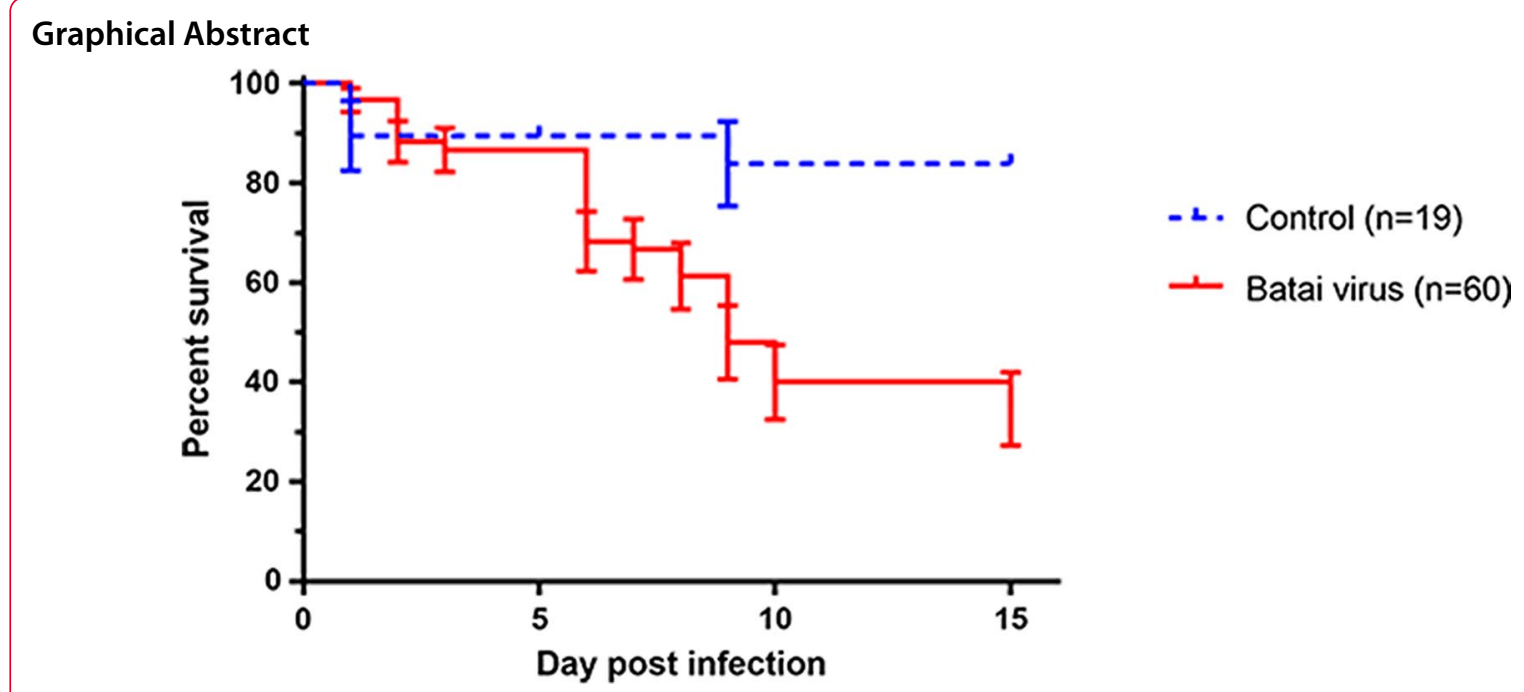

Batai virus (BATV) was originally isolated from Culex gelidus mosquitoes from the Batai area of Kuala Lumpa in Malaysia in 1955 [1]. Antigenic studies subsequently showed it to be identical to Čalovo virus, which had been isolated from Anopheles maculipennis sensu lato (s.l.) mosquitoes trapped in southern Slovakia in 1960 [1]. Both isolates are now formally recognised as Batai orthobunyavirus and classified within the genus Orthobunyavirus of the family Peribunyaviridae [2]. The BATV genome consists of three negative-sense single-stranded RNA segments, namely, the 948-base pair (bp) small (S) segment, the 4448-bp medium-sized (M) segment and the 6874-bp large (L) segment [3], which all code for structural and non-structural proteins of the virus. BATV is transmitted by mosquitoes during feeding and is widely distributed throughout Africa, Asia and Europe [4]. Strains of BATV in India have been isolated from Anopheline and Culex mosquito species and from pigs (Sus scrofa) [4]. Although the zoonotic potential of BATV in Europe is unclear [5], in Africa, BATV has been isolated from humans with symptoms of a febrile illness [6], and Ngari virus, which has been isolated from patients in Africa with haemorrhagic fever, is considered to be a reassortant virus containing the $\mathrm{M}$ segment of BATV and the $\mathrm{S}$ and $\mathrm{L}$ segments from Bunyamwera virus [7].

Active surveys have detected evidence of BATV infection in mosquitoes across central Europe, most recently in regions of Germany [8, 9] and Italy [10]. Furthermore, surveillance for anti-BATV neutralising antibodies in cattle sampled between 2011 and 2012 in Germany indicated a seroprevalence level of $0.6 \%$ [11]. However, more recent studies from Germany have identified seroprevalence levels of $36.4 \%$ [12] and $41.4 \%$ [13], suggesting either an underestimation of seroprevalence in
2011-2012 or that BATV has recently emerged in these areas and can be considered an epizootic in northern Europe. The identification of cattle as a key reservoir species is further corroborated by the isolation of BATV from cattle sera sampled from Inner Mongolia, China [14]. Initial isolations of BATV from mosquitoes strongly favoured transmission by An. maculipennis s.l. [8, 15], but studies in Europe have detected the virus in a range of species, including Culux pipiens and Aedes vexans [9]. This indicates that more than one species of mosquito is susceptible to infection with BATV and might be capable of transmitting the virus to vertebrate hosts. Given that different mosquito species have different feeding preferences, multiple competent vectors may increase the likelihood of pathogen transmission, spillover and disease spread, all of which can impact emergent and endemic disease.

To investigate the vector competence of different mosquito genera, we have assessed the infection, dissemination and transmission rates of BATV in three mosquito species, two Aedes and one Culex species. Given that all three species are known vectors of arthropod-borne viruses, we predict that all three species will be susceptible to BATV infection under our experimental conditions. Furthermore, as Aedes detritus is a competent vector for a range of arthropod-borne viruses that infect domestic animals such as Japanese encephalitis virus [16], West Nile virus [17] and Rift Valley fever virus [18] and that Ae. detritus feeds on cattle in the UK [19], we predict that Ae. detritus will be a competent vector for BATV. Previous work has shown that temperatures above $25{ }^{\circ} \mathrm{C}$ can lead to increased mortality of virus infected mosquitoes indigenous to the United Kingdom [20]. In order to reflect a typical summer temperature in the 
United Kingdom [21], when mosquito activity is at its peak, all experiments were conducted at $20^{\circ} \mathrm{C}$.

BATV (strain 53.2) was isolated in Germany (GenBank accession numbers HQ455790, HQ455791 and HQ455792 for segments S, L and M, respectively) from An. maculipennis s.l. mosquitoes [8]. All following procedures were carried out in a dedicated biosafety level 3 laboratory. BATV was propagated and titrated in Vero cells using a previously described protocol [22]. This resulted in virus stocks maintained in Eagles minimum essential media of suitable concentrations which were kept in a $-80^{\circ} \mathrm{C}$ freezer until required.

Laboratory colonies of Aedes aegypti strain AEAE, West Africa, donated by the London School of Hygiene and Tropical Medicine (London, UK), and Cx. pipiens strain Brookwood, UK (hybrid of forms pipiens and molestus), supplied by The Pirbright Institute (Pirbright, Surrey, UK), were maintained at $25{ }^{\circ} \mathrm{C}$ on sucrose solution. Pupae of Ae. detritus were caught from Dee Marsh, Cheshire, UK $\left(53^{\circ} 16^{\prime} 39.48^{\prime \prime} \mathrm{N}, 3^{\circ} 4^{\prime} 5.286^{\prime \prime} \mathrm{W}\right)$ and reared to the adult stage following protocols described to those described in [22, 23].

Three- to five-day-old, unfed, adult females of each mosquito species were tested for their susceptibility to infection by oral challenge and their competency to vector BATV at $20{ }^{\circ} \mathrm{C}$. Prior to feeding, mosquitoes were transferred to an insect cage $(22 \times 22 \times 22 \mathrm{~cm}$; bugzaare. co.uk, Suffolk, UK) and starved of sucrose for $5 \mathrm{~h}$ to stimulate feeding. Groups of mosquitoes were offered a blood meal containing defibrinated horse blood, adenosine $5^{\prime}$-triphosphate (final concentration: $0.02 \mathrm{mM}$ ) and virus at a final concentration between $1.4 \times 10^{4}$ and $5.5 \times 10^{6}$ plaque-forming units $(\mathrm{PFU}) / \mathrm{ml}$ (Table 1) through a membrane feeding system (Hemotek Ltd., Accrington, Lancashire, UK) and allowed to feed overnight. Following the overnight feeding, cages of mosquitoes were anaesthetised with trimethylamine (FlyNap ${ }^{\circledR}$; Blades Biological Limited, Edenbridge, UK) and engorged mosquitoes separated from unfed individuals. Blood-fed mosquitoes were held in cages within an incubator set at $20{ }^{\circ} \mathrm{C}$ for 7 or 14 days. At the designated time point, mosquitoes were caught using a battery-powered, hand-held aspirator, and while still in the aspirator immobilised by being placed for $2 \mathrm{~min}$ at $-80{ }^{\circ} \mathrm{C}$. The immobilised mosquitoes were then placed on a surface chilled by ice to ensure they remained immobile during removal of the legs/ wings and saliva collection; the bodies were retained. RNA was extracted as previously described [22]. Control groups for Ae. detritus, Ae. aegypti and Cx. pipiens were provided a blood meal without virus.

BATV RNA was detected using a semi-quantitative reverse transcription (RT)-PCR protocol that targets a 99-bp sequence of the $S$ segment using the primers BATV-Forward (5'-GCTGGAAGGTTACT GTA TTT AATAC-3'), BATV-Reverse (5'-CAAGGAATCCAC TGAGTCTGTG-3') and BATV-Probe (5'-FAM-AAC AGTCCAGTTCCAGACGATGGTC-BHQ-1-3') [8]. The PCR reactions were performed with the $\mathrm{iTaq}^{\mathrm{T}}$ Universal $^{\mathrm{M}}$ Probes One-Step Kit (Bio-Rad Laboratories, Hercules, CA, USA) using the following reaction mix per microtube: RNase-free water $(7 \mu \mathrm{l}), 2 \times$ iTaq universal probes reaction mix $(12 \mu \mathrm{l}), 1 \mu \mathrm{l}$ of each primer and probe at $10 \mathrm{pmol} / \mu \mathrm{l}, 1 \mu \mathrm{l}$ of iScript reverse transcriptase and $2 \mu \mathrm{l}$ of extracted RNA. Amplification was conducted using a MxPro 3005 thermal cycler (Agilent Technologies, Santa Clara, CA, USA) using the following reaction conditions:

Table 1 Infection, dissemination and transmission rates of Aedes aegypti, Aedes detritus and Culex pipiens following consumption of a blood meal containing Batai virus

\begin{tabular}{|c|c|c|c|c|c|}
\hline Mosquito species & $\begin{array}{l}\text { Blood-meal titre (in } \\
\text { PFU) }\end{array}$ & Blood-feeding rate, $n$ (\%) & Rate & $\begin{array}{l}\text { Day post-infection } 7, \\
n(\%)\end{array}$ & $\begin{array}{l}\text { Day post- } \\
\text { infection 14, } \\
n(\%)\end{array}$ \\
\hline \multirow[t]{3}{*}{ Aedes aegypti } & $5.5 \times 10^{6}$ & $145 / 320(45)$ & Infection & $4 / 16(25)$ & $3 / 44(7)$ \\
\hline & & & Dissemination & 0 & 0 \\
\hline & & & Transmission & 0 & 0 \\
\hline \multirow[t]{3}{*}{ Aedes detritus } & $1.4 \times 10^{4}$ & $80 / 112(74)$ & Infection & $12 / 15(80)$ & $13 / 16(81.2)$ \\
\hline & & & Dissemination & $5 / 12(41.6)$ & $4 / 13(30.7)$ \\
\hline & & & Transmission & $5 / 5(100)$ & $1 / 4(24)$ \\
\hline \multirow[t]{3}{*}{ Culexpipiens } & $5.5 \times 10^{6}$ & $60 / 188(32)$ & Infection & $1 / 15(7)$ & $1 / 28(4)$ \\
\hline & & & Dissemination & $0 / 1(0)$ & $0 / 1(0)$ \\
\hline & & & Transmission & 0 & 0 \\
\hline
\end{tabular}

PFU Plaque-forming units

Groups of mosquitoes were maintained at $20^{\circ} \mathrm{C}$ for the indicated time periods $(7$ and 14 days post-infection, at which time points the infection rate (number of positive mosquitoes/number of blood-fed mosquitoes), the dissemination rate (number of mosquitoes with virus detected in legs/total number of infected mosquitoes and transmission rate (number of mosquitoes with virus detected in saliva/total number of mosquitoes with disseminated infection) were determined 
reverse transcription at $50{ }^{\circ} \mathrm{C}$ for $10 \mathrm{~min}$, reverse transcriptase inactivation at $95{ }^{\circ} \mathrm{C}$ for $5 \mathrm{~min}$ and PCR amplification and detection at $95^{\circ} \mathrm{C}$ for $10 \mathrm{~s}, 55^{\circ} \mathrm{C}$ for $30 \mathrm{~s}$ for 40 cycles. The amplification files were visualised and analysed in MX3000p v4. software (Agilent Technologies). A sample was to be considered positive for BATV RNA at a Ct threshold value of $\leq 38$.

To determine the susceptibility of particular mosquito species to BATV infection, females of the two Aedes species and one Culex species were each provided a blood meal containing a BATV strain recently isolated in Germany. Blood-fed individuals from each species were divided into two groups and maintained at $20{ }^{\circ} \mathrm{C}$ for either 7 or 14 days. Individual mosquitoes were then tested for infection (virus detected in body), dissemination (virus detected in leg/wings) and transmission (virus detected in expectorated saliva). At $20{ }^{\circ} \mathrm{C}, 25 \%(n=16)$ of Ae aegypti mosquitoes were infected with BATV at day 7 post-infection (dpi) (Table 1); this dropped to $7 \%$ ( $n$ $=44$ ) at $14 \mathrm{dpi}$. No evidence for virus dissemination or transmission was detected in this species at either time point.

For Ae. detritus, infection rates of $80 \%(n=80)$ and $81.2 \%(n=16)$ were detected at 7 and $14 \mathrm{dpi}$, respectively. Dissemination occurred at both time points, with $100 \%$ of mosquitoes in which dissemination had occurred expectorating BATV in saliva at $7 \mathrm{dpi}(n=5)$, although this rate dropped to $25 \%(n=4)$ of disseminated infection at $14 \mathrm{dpi}$. Of the 80 mosquitoes that took a BATV infectious blood meal, we were able to detect only six mosquitoes (7.5\%) with BATV in the saliva under our experimental conditions. The presence of virus in $A e$. detritus bodies, legs and saliva at $14 \mathrm{dpi}$ was confirmed by the isolation of virus in Vero cells using a plaque assay and published methods, and corroborated by the results of the RT-PCR assays on RNA extracted from the isolation culture. Comparison of BATV-infected Ae. detritus to a control group provided with a blood meal with no virus showed that mortality in the BATV-infected group increased from 5 dpi onwards, with $40 \%(n=112)$ surviving to 14 dpi compared to $>80 \%(n=32)$ surviving in the control group (Fig. 1). No differences in mortality were found for the control groups for Ae. aegypti and $C x$. pipiens (data not shown). Culex pipiens showed low levels of infection at day $7(7 \%, n=15)$ and day $14(4 \%, n=$ 28). However, no evidence for dissemination or transmission was shown in this species.

The risk of mosquito-borne virus transmission in Europe has increased in recent years due to the spread of invasive mosquito species [24] and the introduction of pathogens through human travel, as shown by the outbreaks of chikungunya and dengue fever [25], and bird migration [26]. Due to the benefits of a cooler maritime climate and geographical separation from the European mainland, the emergence of such viruses in the UK has been limited so far, but increased summer temperatures have made the UK susceptible to the emergence of mosquito-borne viruses that are present in countries of northwestern Europe [27]. Continued vigilance and the assessment of potential risk are needed to fully understand the likelihood of such virus emergence and their ability to spread [28]. In this study, we have shown that at a low temperature $\left(20^{\circ} \mathrm{C}\right)$, indigenous $C x$. pipiens mosquitoes and the exotic species Ae. aegypti are not vector competent to transmit BATV. This may be due to the limited ability of BATV to replicate in these

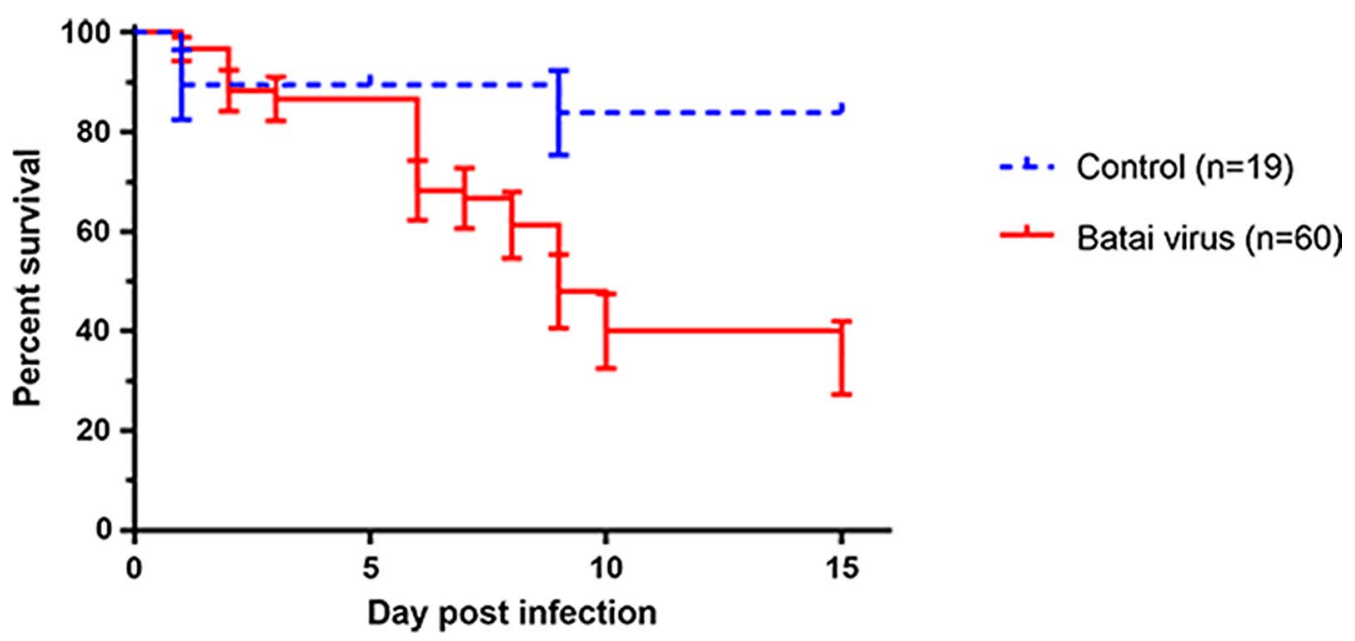

Fig. 1 Survival curves for Aedes detritus at $20^{\circ} \mathrm{C}$ following ingestion of a blood meal that either contained Batai virus (red) or did not (blue) over a 14-day period 
species, although evidence for infection was found in the mosquito body samples. Alternatively, this could reflect that the lower temperature $\left(20^{\circ} \mathrm{C}\right)$ at which the mosquitoes were maintained is limiting virus replication [20], although other factors, such as variation in humidity and daily temperature, are also important. Two different virus concentrations $\left(10^{4}\right.$ and $\left.10^{6} \mathrm{PFU}\right)$ were used in the experiments as they were undertaken with newly produced stocks at different time frames. No difference in infection rates was recorded at the higher titres $\left(10^{6} \mathrm{PFU}\right)$ between Ae. aegypti and $C x$. pipiens in comparison to lower titres in Ae. detritus ( $\left.10^{4} \mathrm{PFU}\right)$ (Table 1$)$.

A recent investigation of vector competence for Chittoor virus, an Asian variant of BATV, in Culex quinquefasciatus, Culex tritaeniorhynchus and Ae. aegypti showed that the Culex species were vector competent but Ae. aegypti was not, although again infection was also observed in that species [29]. By contrast, we have shown that Ae. detritus was highly susceptible to infection with BATV, resulting in dissemination and potential transmission at both 7 and 14 days following ingestion of a blood meal. However, this was also associated with increased mortality compared to a non-infected control group. This result suggests that virus replication, sufficient to enable dissemination, may be detrimental to mosquito survival.

Aedes detritus populations are found in many coastal regions of the UK. This species also appears to be competent to transmit a growing list of exotic mosquitoborne viruses $[16-18,30]$ at temperatures between $20^{\circ} \mathrm{C}$ and $25^{\circ} \mathrm{C}$, now including BATV. The mosquito is mammalophilic, aggressively biting a range of species, including humans and ruminant livestock. As a result, it could play a critical role in maintaining and transmitting exotic mosquito-borne viruses to susceptible species, including humans. The widespread distribution of BATV in mainland Europe [31] and its wide vertebrate host range, including its recent detection in harbour seals in northern Germany [32], suggests that the virus has the potential to emerge in the UK in the near future.

In conclusion, all three mosquito species studied could be experimentally infected with BATV at $20^{\circ} \mathrm{C}$. However, there was no evidence that the virus could disseminate in Ae. aegypti or $C x$. pipiens at this temperature at either 7 or 14 days post-infection. By contrast, Ae. detritus proved to be highly susceptible to infection as early as $7 \mathrm{dpi}$. Dissemination occurred in a proportion of those infected, and BATV was detected in the saliva of these mosquitoes by RT-PCR and plaque assay (tested at $14 \mathrm{dpi}$ ), suggesting the potential to transmit this virus. Considering the widespread presence of BATV across Europe and the host-feeding preference of Ae. detritus for livestock, these results highlight a potential epizootic risk should this virus be introduced into the UK.

\section{Acknowledgements}

The authors thank Shahida Begum (London School of Hygiene and Tropical Medicine, UK) for providing Ae. aegypti eggs. The Cx. pipiens mosquitoes used in this study were provided by the Pirbright Institute under UK Grant Code BBS/E/I/0007039 awarded to Simon Carpenter as part of funding received from the Biotechnology and Biological Science Research Council (UK Research and Innovation). The authors also thank Jonas Schmidt-Chanasit (Bernhard Nocht Institute, Hamburg, Germany) for providing the BATV (strain 53.2).

\section{Authors' contributions}

ARF, LMM obtained funding for the study. LMHT, SL and AF conceived and designed experiments. $L M H T, A F, E B, S L$ and MF performed the experiments. $L M H T, A F, E B, S L, M F, S S, L M M$, ARF and NJ analysed the data. LMHT wrote the first draft. NJ revised the draft. All authors read and approved the final manuscript.

\section{Funding}

Funding was provided by the European Union Framework Horizon 2020 Innovation Grant European Virus Archive Global (EVAg, No. 653316) and the Department for Environment, Food and Rural Affairs (Defra), The Scottish Government and Welsh Government through Grant SV3045.

\section{Availability of data and materials}

All data generated by this study and used is presented within this published article.

\section{Declarations}

Ethics approval and consent to participate

Not applicable.

\section{Consent for publication}

Not applicable.

\section{Competing interests}

The authors declare that they have no competing interests.

\section{Author details}

${ }^{1}$ Vector-Borne Diseases Research Team, Virology Department, Animal and Plant Health Agency, Woodham Lane, Addlestone KT15 3NB, Surrey, UK. ${ }^{2}$ Microbiology Services Division, Public Health England, Porton Down, Wiltshire, UK.

Received: 31 August 2021 Accepted: 15 October 2021

Published online: 03 November 2021

References

1. Hubálek Z. Mosquito-borne viruses in Europe. Parasitol Res. 2008;1:S29-43.

2. International Committee on Taxonomy of Viruses (ICTV). Genus: Orthobunyavirus. https://talk.ictvonline.org/ictv-reports/ictv_online_report/negat ive-sense-rna-viruses/w/peribunyaviridae/1238/genus-orthobunyavirus. Accessed 13 Apr 2021.

3. Groseth A, Matsuno K, Dahlstrom E, Anzick SL, Porcella SF, Ebihara H. Complete genome sequencing of four geographically diverse strains of Batai virus. J Virol. 2012;86:13844-5.

4. Yadav PD, Sudeep ABB, Mishra AC, Mourya DT. Molecular characterization of Chittoor (Batai) virus isolates from India. Indian J Med Res. 2012;136:792-8.

5. Hubálek Z, Zeman P, Halouzka J, Juricová Z, St'ovíková H, Sikutová S, et al. Antibodies against mosquito-borne viruses in human populations of an area of Central Bohemia affected by the flood of 2002. Epidemiol Mikrobiol Immunol. 2004;52:112-20.

6. Nashed NW, Olson JG, El-Tigrani A. Isolation of Batai virus (Bunyaviridae: Bunyavirus) from the blood of suspected malaria patients in Sudan. Am J Trop Med Hyg. 1993;48:676-81. 
7. Gerrard SR, Li L, Barrett AD, Nichol ST. Ngiri virus is a Bunyamwera virus reassortant that can be associated with large outbreaks of haemorrhagic fever in Africa. J Virol. 2004;78:8922-6.

8. Jöst H, Bialonski A, Schmetz C, Günther S, Becker N, Schmidt-Schanasit J. Isolation and phylogenetic analysis of Batai virus, Germany. Am J Trop Med Hyg. 2011;84:241-3.

9. Scheuch DE, Schäfer M, Eiden M, Heym EC, Ziegler U, Walther D, et al. Detection of Usutu, Sindbis, and Batai viruses in mosquitoes (Diptera: Culicidae) collected in Germany, 2011-2016. Viruses. 2018;10:389.

10. Huhtamo E, Lambert AJ, Costantino S, Servino L, Krizmancic L, Boldorini $\mathrm{R}$, et al. Isolation and full genomic characterization of Batai virus from mosquitoes, Italy 2009. J Gen Virol. 2013;94:1242-8.

11. Hoffman M, Wiethölter A, Blaha I, Jöst H, Heinemann P, Lehmann M, et al. Surveillance of Batai virus in bovines from Germany. Clin Vaccine Immunol. 2015;22:672-3.

12. Ziegler U, Groshup MH, Wysocki P, Press F, Gehrmann B, Fast C, et al. Seroprevalance of Batai virus in ruminants from East Germany. Vet Microbiol. 2018;227:97-102.

13. Cichon N, Eiden M, Schulz J, Günther A, Wysocki P, Holicki CM, et al. Serological and molecular investigation of Batai virus infections in ruminants from the State of Saxony-Anhalt, Germany, 2018. Viruses. 2021;13:370.

14. Liu H, Shao X-Q, Hu B, Zhao J-J, Zhang L, Zhang H-L, et al. Isolation and complete nucleotide sequence of a Batai virus strain in Inner Mongolia. China Virol J. 2014;11:138.

15. Calzolari M, Bonilauri P, Bellini R, Caimi M, Defilippo F, Maioli G, et al. Arboviral survey of mosquitoes in two northern Italian regions in 2007 and 2008. Vector Borne Zoonotic Dis. 2010;10:875-84.

16. Mackenzie-Imponvil L, Impoinvil DE, Galbraith SE, Dillon RJ, Ranson H, Johnson N, et al. Evaluation of a temperate climate mosquito, Ochleratutus detritus (= Aedes detritus), as a potential vector of Japanese encephalitis virus. Med Vet Entomol. 2015;29:1-9.

17. Blagrove MS, Sherlock K, Chapman GE, Impoinvil DE, McCall PJ, Medlock $J M$, et a.. Evaluation of the vector competence of a native UK mosquito Ochlerotatus detritus (Aedes detritus) for dengue, chikungunya and West Nile viruses. Parasit Vectors. 2016;9:452.

18. Lumley S, Hernández-Triana LM, Horton DL, Fernández de Marco MDM, Medlock JM, Hewson R, et al. Competence of mosquitoes native to the United Kingdom to support replication and transmission of Rift Valley fever virus. Parasit Vectors. 2018;11:308.

19. Brugman VA, Hernández-Triana LM, England ME, Medlock JM, Mertens PP, Logan JG, et al. Blood-feeding patterns of native mosquitoes and insights into their potential role as pathogen vectors in the Thames Estuary. Parasit Vectors. 2017;10:163.

20. Folly AJ, Dorey-Robinson D, Hernández-Triana LM, Ackroyd S, Vidana B, Lean FZX, et al. Temperate conditions restrict Japanese encephalitis virus infection to the mid-gut and prevents systemic dissemination in Culex pipiens mosquitoes. Sci Rep. 2021;11:6133.

21. UK Met Office. UK climate averages. https://www.metoffice.gov.uk/resea rch/climate/maps-and-data/uk-climate-averages/gcpevmgzn. Accessed 4 Aug 2021.

22. Hernández-Triana LM, de Marco MF, Mansfield KL, Thorne L, Lumley S, Marston D, et al. Assessment of vector competence of UK mosquitoes for Usutu virus of African origin. Parasit Vectors. 2018;11:381.

23. Hernández-Triana LM, Barrero E, Delacour-Estrella S, Ruiz-Arrondo I, Lucientes J, Fernández de Marco MDM, et al. Evidence for infection but not transmission of Zika virus by Aedes albopictus (Diptera: Culicidae) from Spain. Parasit Vectors. 2019;12:204.

24. Schaffner F, Medlock JM, Van Bortel W. Public health significance of invasive mosquitoes in Europe. Clin Microbiol Infect. 2013;19:685-92.

25. Barzon L. Ongoing and emerging arbovirus threats in Europe. J Clin Virol. 2018;107:38-47.

26. Chaintoutis SC, Papa A, Pervanidou D, Dovas CI. Evolutionary dynamics of lineage 2 West Nile virus in Europe, 2004-2018: Phylogeny, selection pressure and phylogeography. Mol Phylogenet Evol. 2019;141:106617.

27. Folly AJ, Lawson B, Lean FZ, McCracken F, Spiro S, John SK, et al.. Detection of Usutu virus infection in wild birds in the United Kingdom, 2020. Euro Surveill. 2020;25:2001732.

28. Folly AJ, Dorey-Robinson D, Hernández-Triana LM, Phipps LP, Johnson N Emerging threats to animals in the United Kingdom by arthropod-borne diseases. Front Vet Sci. 2020;7:20

29. Sudeep AB, Shaikh N, Ghodke YS, Ingale VS, Gokhale MD. Vector competence of certain Culex and Aedes mosquitoes for the Chittoor virus, the Indian variant of the Batai virus. Can J Microbiol. 2018;64:581-8.

30. Chapman GE, Sherlock K, Hesson JC, Blagrove MSC, Lycett GJ, Archer D, et al. Laboratory transmission potential of British mosquitoes for equine arboviruses. Parasit Vectors. 2020;13:413.

31. Dutuze FM, Nzayirambaho M, Mores CN, Christofferson RC. A review of Bunyawera, Batai, and Ngari viruses: understudies Orthobunaviruses with potential one health implications. Front Vet Sci. 2018;5:69.

32. Jo WK, Pfankuche VM, Lehmberker A, Martina B, Rubio-Garcia A, Becker S, et al. Association of Batai virus infection and encephalitis in harbour seals, Germany, 2016. Emerg Infect Dis. 2018;24:1691-5.

\section{Publisher's Note}

Springer Nature remains neutral with regard to jurisdictional claims in published maps and institutional affiliations.
Ready to submit your research? Choose BMC and benefit from:

- fast, convenient online submission

- thorough peer review by experienced researchers in your field

- rapid publication on acceptance

- support for research data, including large and complex data types

- gold Open Access which fosters wider collaboration and increased citations

- maximum visibility for your research: over $100 \mathrm{M}$ website views per year

At BMC, research is always in progress.

Learn more biomedcentral.com/submissions 